\section{Unemployed nurses}

In a reply to a question on 16 May about unemployed nurses $\mathrm{Mr}$ Roland Moyle stated that the latest figures showed that there were 3821 qualified nurses registering as unemployed in England in March 1977. Figures were not available to show the total number of wards "currently closed or not opened specifically because of a shortage of staff."

\section{MEDICAL NEWS}

\section{New professor at Nottingham}

Dr Tom Arie has been appointed to the foundation chair of health care of the elderly at the University of Nottingham from 1 September 1977. Dr Arie, who is 43, qualified from Oxford in 1960, and trained in psychiatry at the Maudsley Hospital, later becoming senior lecturer in the department of social medicine at the London Hospital Medical College. He is at present consultant psychiatrist at Goodmayes Hospital and honorary senior lecturer at University College Hospital Medical School. His main interest at Goodmayes Hospital has been the development of a comprehensive psychiatric service for old people, and he is interested in social and medical policy for the elderly, education, and the work satisfaction of staff in the NHS. He was a member of the Government Working Party on Social Work Support for the Health Service and he represents the Joint Consultants Committee on the Central Council for Education and Training in Social Work.

\section{New professor of surgery at the University of Leeds}

Professor David Johnston has been appointed to the chair of surgery at Leeds General Infirmary and the headship of the

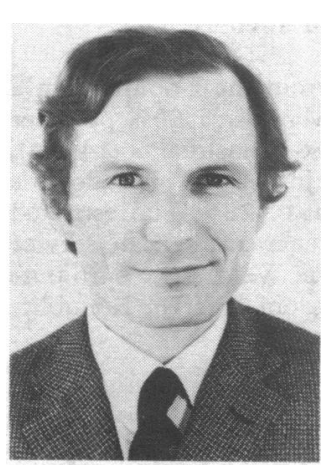
department in succession to Professor J C Goligher from 1 October, 1977. Professor Johnston, who is 40, was research assistant and registrar at Leeds General Infirmary from 1962 to 1964 moving to Sheffield in 1964 as lecturer in surgery and senior registrar at Sheffield

Royal Infirmary. He then returned to Leeds as senior lecturer, later reader, in surgery and consultant surgeon. In 1975 he was appointed to the chair of surgery at Bristol. Professor Johnston specialises in the surgical physiology of the upper gastrointestinal tract.

\section{Nuffield Nursing Homes Trust}

In its 1976 annual report Nuffield Nursing Homes Trust reports continued growth. During the year over 35000 patients were admitted to its 26 homes, an increase of $10 \%$ over the previous 12 months. A small surplus of $£ 200000$ was achieved, the cost of running the homes being $£ 7 \mathrm{~m}$. In 1976 about $£ 2.5 \mathrm{~m}$ was spent on fixed assets and building work in progress. Two new hospitals were commissioned at Hove and Enfield and a hospital near Southampton has just opened. Extensions are planned to expand facilities at several existing homes. Currently appeals are in progress at Newcastle-under-Lyme, Wolverhampton, and Leeds which should add a further 100 beds to the Trust's facilities. The new chairman, $\mathrm{Mr} \mathrm{H}$ S Axton, drawing attention to the continued generous public support to the NNHT appeals, described it as showing the importance that many people attach to private treatment.

\section{Fees for part-time medical services}

Agreement has been reached with the following organisations for the increase of $32.27 \%$ approved by the Price Commission (2 April, p 925), to be applied to fees for part-time medical services.

Life Offices Association: for completion of life assurance reports (effective date 1 June 1977).

The Association of British Adoption Agencies: for the completion of the standard forms used in adoption procedures (effective date 1 April 1977).

British Red Cross Society, St John Ambulance Association, and St Andrew's Ambulance Association: fees for lectures to the lay public on first aid, and examinations.

The increase of $50 \%$ approved by the Price Commission in the fees for doctors attending colliery emergencies has been agreed by the National Coal Board (effective date 1 April 1977)

Details of the revised fees can be obtained from the Secretary, BMA House, Tavistock Square, London WC1H 9JP, or from BMA regional offices.

\section{BMA Annual Meeting, Glasgow: graduates' dinners}

The following graduates' dinners will be held on Tuesday, 19 July:

The Cambridge dinner will be held in the Central Hotel, Glasgow: ticket $£ 7 \cdot 50$.

The Glasgow dinner will be held in the Randolph Hall, Glasgow University: ticket $£ 7 \cdot 50$.

\section{People in the News}

Mr D P Choyce has succeeded Dr C D Binkhorst as president of the International Intraocular Implant Club.

\section{COMING EVENTS}

Royal College of Physicians of LondonTeach-in on "Advances in viral hepatitis," 14 June, London. For details see advertisement at p vii.

"The elderly person with failing vision"Seminar organised jointly by the University of Manchester Department of Geriatric Medicine and the Disabled Living Foundation, 29 June, Manchester. Details from Disabled Living Foundation, 346 Kensington High Street, London W14 8NS.

\section{SOCIETIES AND LECTURES}

For attending lectures marked * a fee is charged or a tickes is required Applications should be made first to the institution concerned.

Wednesday, 8 June

INSTITUTE OF PsychiatRy- $5.30 \mathrm{pm}$, Dr D F Benson (USA). Anomia and the process of finding Benson OXFORD UNIVRST and the process Laboratory of Physiology, $8.15 \mathrm{pm}$, Sir Francis Avery Jones: Getting the NHS back on course.

ROYAL COLLEGE OF PSYCHIATRISTS PSYCHOTHERAPY SPECIALIST SECTION-At Royal Society of Medicine, $8.15 \mathrm{pm}$, Dr J Bowlby: The therapeutic implication of attachment therapy.

RoYal College OF SURGEONS OF ENGLAND-Hunterian ecture by Professor G A Kune: Life-threatening surgical infection: its development and prediction. bourne): Metabolic bypass.

UNIVERSITY OF OXFORD-At John Radcliffe Hospital, $4 \mathrm{pm}$, Professor F Hytten: Is viviparity the best way to reproduce the species?

Thursday, 9 June

Royal College of Surgeons of ENGland-At Institute of Ophthalmology, Cayton Street, $3 \mathrm{pm}$, Professor W S Foulds: The retinal, pigment epithelial interface. At Royal College of Surgeons of England, $5 \mathrm{pm}$, Gordon-Taylor Memorial lecture by Professor L P Le Quesne: The remote consequences of gastric surgery. RoYAL Socrery - $4.30 \mathrm{pm}$, Professor $R \mathrm{~J} P$ Williams,
FRS: Energy states of proteins, enzymes, and membranes.

\section{BMA NOTICES}

\section{Division Meetings to be Held}

Members proposing to attend meetings marked * are asked to notify in advance the honorary secretary concerned.

Aldershot and Farnham-At New Mill Restaurant, Thursday, 9 June, 7 for $7.30 \mathrm{pm}$, annual dance.

Eastbourne-At Towner Art Gallery, Wednesday, June, $7.30 \mathrm{pm}$, annual ladies' night.

Green Hill, Saturday, 11 June, $7.30 \mathrm{pm}$, Jubilee ball organised by the Guests are invited.

Leicestershire and Rutland-At Leicester Royal Infirmary, Thursday, 16 June, $8 \mathrm{pm}$, agm.

\section{Corrections}

\section{Diet and coronary heart disease}

We regret that a printing error occurred in the letter from Dr Keith Ball (21 May, p 1346). The last sentence of the first paragraph should read: "Sir John is naturally concerned to prevent unnecessary dietary advice being given to the public. ..."

Primary care: a look at Kenya

We are informed that Medicine Digest is published by Medicine Digest Limited of London, not the African Medical and Research Foundation.

\section{Notice to authors}

When original articles and letters for publication are not submitted exclusively to the British Medical fournal this must be stated. For detailed instructions to authors see page 6 of the issue dated 1 January 1977.

Correspondence on editorial business should be addressed to the Editor, British Medical fournal, BMA House, Tavistock Square, London WC1H 9JR. Telephone: 01-387 4499. Telegrams: Aitiology, London WC1. Communications will not be acknowledged unless a stamped addressed postcard or an international reply coupon is enclosed.

Authors wanting reprints of their articles should notify the Publishing Manager, BMA House, Tavistock Square, WC1H 9JR, on receipt of proofs.

\section{(C) British Medical Journal 1977}

All Rights Reserved. No part of this publication may be reproduced, stored in a retrieval system, or transmitted, in any form or by any means, electronic, mechanical, photocopying, recording or otherwise, without the prior permission of the British Medical fournal. 